\title{
ON HYALURONIDASE SPREADING REACTION IN VERIOUS SKIN DISEASES (4 th Report)
}

Investigation for Skin Constitution by Means of Hyaluronidase

\section{Korehiro TAKEDA}

(Dept. of Dermatology, School of Medicine Tokushima University)

(National Leprosarium Oshima Seishoen)

Comparative studies of HSR were carried out between hyaluronidase and that added with trypan blue, applying to the normal, verious dermatoses, leprosy and other diseases.

1) In the normal and dermatoses trypan blue-HSR and HSR showed a similar tendency and the average values were the same. The reactional areas of HSR alone were larger than that of trypanblue HSR.

2) Sexual differences of HSR was observed (male $>$ female). It was also influenced by the kinds and conditions of the diseases. Namely, in the acute diseases HSR increased. In leprosy HSR was specifically negative in $13.3 \%$ of lepromatous, in $6.1 \%$ of neural and $21.4 \%$ of macular leprosy.

3) HSR in the urological diseases was similar to that of the normal, while it was decreased in anuria, cancer and diabetes

4) In dermatological patients, there was observed no direct connection between HSR and the decrease of eosinophile leucocytes.

\section{各種疾患々者の Hyaluronidase 拡散反応について}

\section{（Hyaluronidase による皮䖉素因の検討＼cjkstart第 4 報）}

\author{
武田 巳 広 \\ 德島大学医学部皮膚必原器科教窒 (指導 荒川忠良教授) \\ 国立療養所大島青松徍 \\ （指導 野島泰治園長）
}

(昭和 31 年 5 月 3 日 受稿)

\section{緒言}

私共はさきに Trypan 青を標示薬よして皮内に注射し た Hyaluronidase（Hと略記）の皮内に括ける拡散学健

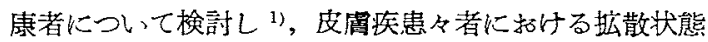
12) とは全く異なるととを報告した。その後私共はH S R は色素を加えなくてる，即ちH液のみを皮内に注射して 充分号の应散坆観察し得られ，雨者の成績は大体一致 するとと，かつ反応性紅斑の程度が観察し得られる利点

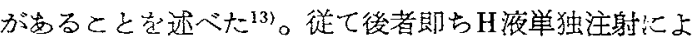
り泫散と登赤を目標とする方法（H抬散反応，以下HSR と略記）を健鹿者に応用して 1 時間值と24時間值の比較
を前報したので ${ }^{33}$ ，今回は各種疾患々者に応用し，前報 の健疗者に試みた成績，及び Trypan 青一H液を用いた 皮成垁患々者に拁ける成績とを比較することにした。

\section{実験方法}

前報と同樣に Hyaluronidase (Spractor 塩野義) 5000 T R Uを 1 c.c. の生理的食塩水溶解し，その0.1c.c. を Tuberculin 反忍の要領により細心の注意の下に，前腕屈 側上 $1 / 3$ と中 $1 / 3$ の境界部に注射した。抎散度は Sliding

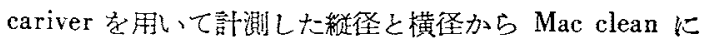
従つて $(\mathrm{S}=\mathrm{D} ・ \mathrm{~d} \pi / 4)$ 面積を算出した。今国は患者を奶 象としたため 1 時間值のみを比较するととにした。 
対象は德島大学皮周科及び议沓器科の外来及び入院患 者夫々91名及び25名であり，瀨患者は大島青松園入園者 を任意に選んだ。但し後者については改めて詳細に模討 することにする。

\section{実験成績}

\section{1. 皮筒疾㶳々者のH S R}

巳きk私共は皮苚疾患々者79名k Trypan 青加 H S R の結果を検討し，矢患の性筫に上り大体特定の拡散面磧 のめるととを報告したので ${ }^{22)}$ ，今回は標示薬を除いて91

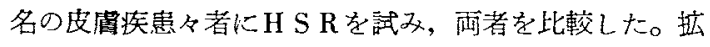

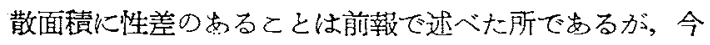

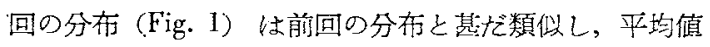
も一定の䐓序炕排列した。乙の際季節的变動については 留意していない。即ら皮唐炎, 急性湿疹, エッテマト一 テス，膿皮症，バザン氏紅斑，紫斑病，天疮癔，結節性

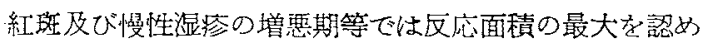
るが，皮膚资，急性湿疹，膿皮症の治療前のむの(

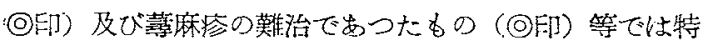

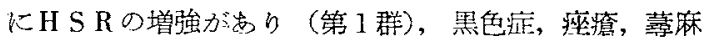

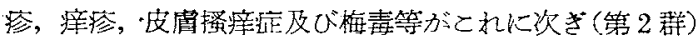

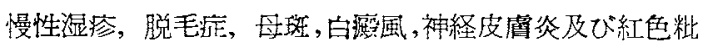

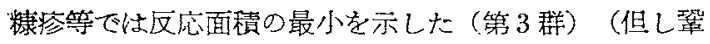
皮症，表皮水疱症その他については各 1 例であるためと

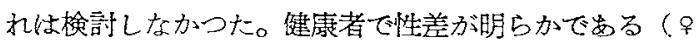

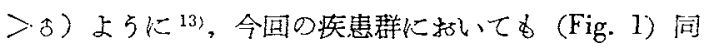
様纪性差を認めるが（平均男子 $4.07 \mathrm{~mm}^{2}$ ，女子 $548.2 \mathrm{~mm}$ 2)，被検数が少いため疾患每に性差を観察することは困

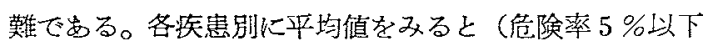
は菓却した)，前報の Trypanblue 加H S R の結果 ${ }^{12} に$ 比較して平均值に相異はあるが全く同し傾向を示して招 り (Tab. 1), 平均値恃大体第 1 群が $514.7 \sim 955.7 \mathrm{~mm}^{2}$, 第 2 群が312.0〜487.5 m² 第 3 群が178.0〜285.3 $\mathrm{mm}^{2}$ の中心包含される。つ苔り第1群は青春期の女子 $(667$. $\left.9 \mathrm{~mm}^{2}\right)$, 第 2 教は7 15才の男子 (365.5 440.7 $\left.\mathrm{mm}^{2}\right)$ 第 3 群は或人男子 $\left(164.0 \sim 258.8 \mathrm{~mm}^{2}\right)$ の S R 值 ${ }^{13}$ 以 相当するもので岁る。反応の强さす大体反応面積と平行 して面積の大きいすのは潮紅も強い上らでする(Tab. 1) 母坟 $\left(285.3 \mathrm{~mm}^{2}\right)$, 痤瘡 $\left(448.6 \mathrm{~mm}^{2}\right)$ ではH S R 增 強があるが，とれは被検者が7〜17才の年少者であつた ためと思われる ${ }^{13)}$ 。しかし襄麻疹，白癌風の各 1 例は反 応面皘が小さいのに絓さが增し，天疱䀠の 2 例，表皮水 疮症の 1 例の如く反忘面程が大きいの纪紅さが弱い場合

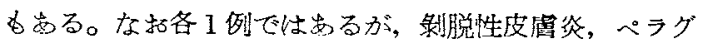

ラ等では反沁面稳及び強さが共に大である。

\section{II 攋患者の H S R}

瀨患者 357 名（男子 250 名, 女子 107 名）のH R R つい検索した。その成樍はTab 2 火示すよらに，I時 閣，24時間後も区応を示さなかつた方のが夫々 Lは 13.3 $\%, 18.7 \%, \mathrm{~N} は 6.1 \%, 6.1 \%, \mathrm{M} 221.4 \%, 21.4 \%$ の高率を占めているととは今回までに相遇しなかつた事 である。病型別にその平均値をみると（伦険率 $5 \%$ 以下 は棵却した）。時間ではM>N>L（M. $474.7 \mathrm{~mm}^{2}$, $\left.\mathrm{N}, 287.7 \mathrm{~mm}^{2}, \mathrm{~L}, 275.8 \mathrm{~mm}^{2}\right)$ の順に小となり，24时 間では $\mathrm{N}<\mathrm{M}<\mathrm{L}\left(\mathrm{N}, 577.8 \mathrm{~mm}^{2}, \mathrm{M}, 461.5 \mathrm{~mm}^{2} \mathrm{~L}\right.$ ， $458.2 \mathrm{~mm}^{2}$ ) の順に小之なり，Lは何れの場合にも HSR が減弱している。性差をみると健展人と同椂にL，Nて は明らかに女子が男子より大きい值宗しているが，M のそれは 1 時間値が健康者炕類似するのに拘らす，24時

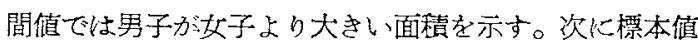
の分散が汉忘面積のどの部分に多いかを娭討するため， 1 時間及び24時間の反応面皘の病犁别被検者数比率を目 示すると (Fig. 2)，1時简值ては

$\begin{array}{ccc}\text { 病型 } & \text { 例数比率 } & \text { 反応面積 } \\ \mathrm{L} & 59.9 \% & 101 \sim 300 \mathrm{~mm}^{2} \\ \mathrm{~N} & 54.8 \% & 101 \sim 300 " \\ \mathrm{M} & 53.5 \% & 101 \sim 400 "\end{array}$

となり Mは L や N に対比して反充面積の分散が大きい。 24時閪值では

\begin{tabular}{|c|c|c|}
\hline 型 & 例数比率 & 反心面積 \\
\hline L & $53.4 \%$ & $201 \sim 500 \mathrm{~mm}^{2}$ \\
\hline N & $\left(\begin{array}{l}57.3 " \prime \\
10.9 "\end{array}\right.$ & $\begin{array}{c}301 \sim 600 " \\
1001 \sim 1500 "\end{array}$ \\
\hline M & $\left(\begin{array}{l}35.7 " \prime \\
14.3 " \prime\end{array}\right.$ & $\begin{array}{r}201 \sim 400 \\
1001 \sim 150\end{array}$ \\
\hline
\end{tabular}

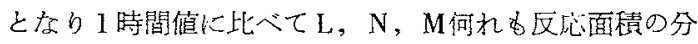
散が大きい $(\mathrm{M}>\mathrm{N}>\mathrm{L})$ ，要するk $\mathrm{L}, \mathrm{N}, \mathrm{M}$ 何れも 多くの場合に24時間が 1 時間值より大きい值を示すよう でめるが，N，M秼にMでは24時間後に反応面積の異常 な増大を来たし，或は 1 時問後に異常に増大して24時間 後には弱小となる場合が案外多いるのと思われる。

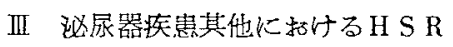

议尿器疾患では大体反応面積は健康者のそれと類似す るよらである (Fig 3)，その平均值は次のようになる。

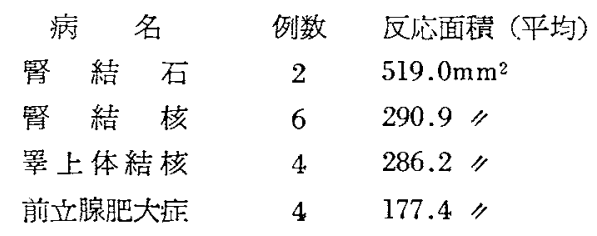




\section{無㲾宊 285.8 "}

つまり反応面䅪は腎結石>腎結核>前立腙肥大泟>睪上 体結核〉無尿症の䐓に小さくなる。無尿症 2 例について の检査は夫々無尿後34時間，38時間後に行つたすのでめ り，何れも反応の減弱があつた（強さ士）, 癌腫 3 例の 中 1 例は荟茥演で胡藏に転移巣を作つた覀液貿の状態に 颃いて H S R を行つたものであるが，反面䅡の増大 $\left(1523.0 \mathrm{~mm}^{2}\right)$ 飞かからわず全く発赤を示さず，他の2

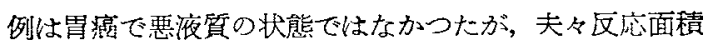
$\left(682.5,302.4 \mathrm{~mm}^{2}\right)$ に比べ赤さか溺い $(-, \pm)$, 楉

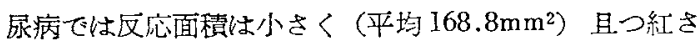
b弱、 $(+, \pm)$

\section{IV 好酸球減少率とH S R}

慢性湿疹 5 名, 円形脱毛症 5 名, 結節性紅玟 3 名, 襄 麻疹 3 名, 皮篔炎 3 名, 急性湿落 2 名計 21 名について好 酸球減少率とH S R の関保をみると, Fig. 4 に示すよ5



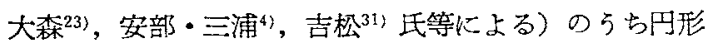

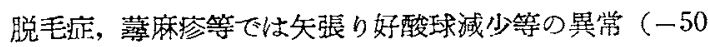
\%以下）を示すものが多いが，それと反応面積の間に直 接相関々係が岕るは思われない。

\section{$\mathrm{V}$ 疾病経過以於る反店面積と好酸球減少率の変化}

急性エリテマトーデス，亜急性エリテマトーデス，制

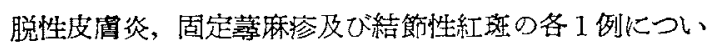
て疾病の経過を追て，HＳ２好酸球減少率を観察した が，その成績でも(Fig. 5) 前に道べた如く両者の間に は必ずしも関連性があると俚思われない。しかし No. 2 3のよ5に大体平行関係を名るものb文る。被検者の中 第 1，4，5例住漸次快方们向い，第 2 例は治療中増 覀，第 3 例は死亡したが，と机等のととからみて，霆々 H S R及び好酸球隇少率の大きい変動を示すことは何等 かの素因を意味するよらに思われる。

\section{総括}

さきに健康者のH S Rでは性差があり（女子子 $667.9 \mathrm{~m}$ $\mathrm{m}^{2}>$ 男子 $215.2 \mathrm{~mm}^{2}$ ) しか力女子ては経時の最强を頂 点として减弱して拁り，季節的にも変動があり（春>弪 >夏>秋)，更心生涯を通しる年令的差異が認められる (奻少年期に最強，成人厄不变）とと老報告した。この 際ッベルクリン反応の転調期，凍澹皮唐炎等何等かの病 的素因がある場合には，H S Rの变化を生起するもので

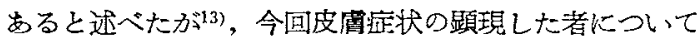
㛟棓し大結果は，果して疾患による一連の条列が得ら れ，疾患心より皮膚拡散性に差のあることを示した。こ
のととはさきに報告した Trypan 青加H液によるH S R の成績 ${ }^{12)}$ と大体一致するもので岕るただ異なる所は一 般にH S R の面積は Trypan 青加H S Rよりも大きい值 を示すととでる。 $400 \times$ 青・加5000TRU・H による反 応像では中央発赤部の外輪が青色を带び, $5000 \times$ Trypan 青加・5000TRU・Hによるそれは中央が青色で外輪に発 赤を生する2)。影口氏は色素を示標として拨散現象をみ る場合は色素か深部に吸収されるととを強調している21， ことから，上記の稀薄な色素を加えたH S R の反応像は 反応性浮腫である外輸まで色素の拉散が起り難いか，或 は極めて薄いために発赤媇われて青色が見えなくな り，結果として判定值が小さくなると考えられる。

反応面積の大小地よて皮度疾患を大体 3 群に分けら れる。即ち第 1 群恃皮眉炎，急性湿疹，慢性湿疹の増悪 期，エリテマトーデス，バザン氏紅斑，結節性紅斑，膿 皮症，紫㙁病，天疮瘡及び慢性荎麻疮等が含まれて最大 であり（514.7〜 955.7 $\left.\mathrm{mm}^{2}\right)$ ，青春期の健康女子のそれ

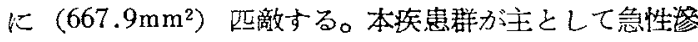

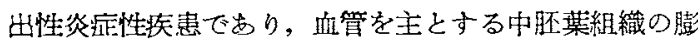
化，変性が冓視されるものであるととは注目に值する。 野口氏21)は土リテマト1デス，ヂニーリング氏皮筒等 で H-Inhibitor の増加があると指摘しているが，私の 成績ではH S Rの増強があるから, Inhibitorの堌加必ず しすH S Rを減弱せしめるものとは思われず，皮㲏の組 織化学各湩視されてよいようでる。第 2 群比属するす

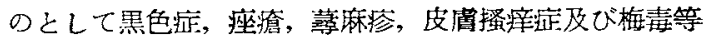
がめり $\left(312.0 \sim 487.5 \mathrm{~mm}^{2}\right)$ 丁度 $7 \sim 15$ 子の健康男子の それk $\left(365.5 \sim 440.7 \mathrm{~mm}^{2}\right)$ 相当するるのである。第 3 群には慢性湿疹，脱毛症，母玟，白撚風，神経皮固炎及 び紅色粃糠疹等が見られ，坮散面積は最小である(178.0

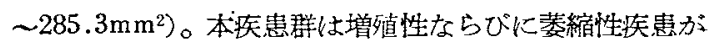
主体をなし，健革成人男子のそれに(164.0〜258.8 $\left.\mathrm{mm}^{2}\right)$ 区敵するものでるる。応の強さ（赤さ）。大体反面 積と平行し，面積の大きいるのは紅さも強いが，套麻疼 白症風の各 1 例の如く, 反応面積が小さいのに紅さが強

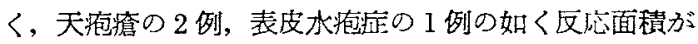
大きいのに紅さが弱、場合する。つまり反応面積と反 応強度があい伴わない場合が志るととは注意されてよ i。

瀨患者は反応性に乏しいととが印象的ですつた。即ら 1 時間及び24時間後る反度を示さなかつたものが相当高

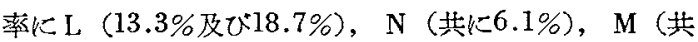
に21.4\%）に見られて扎り，かかるととは煡康者及び皮 膚疾患々者ては全く相遇しなかつかととである 2)12)，反 
面著しく反応するものもまつて，平均值をとれば， 1 時間で性

$M\left(474.7 \mathrm{~mm}^{2}\right)>\mathrm{N}\left(287.7 \mathrm{~mm}^{2}\right)>\mathrm{L}\left(275.8 \mathrm{~mm}^{2}\right)$ の順となり，L，Nの值が成人煡䐂男子のそれ相当す る。

\section{$2 \Delta$ 時間では,}

$\mathrm{N}\left(577.8 \mathrm{~mm}^{2}\right)>\mathrm{M}\left(461.5 \mathrm{~mm}^{2}\right)>\mathrm{L}\left(458.2 \mathrm{~mm}^{2}\right)$ の順に小さい。何れの場合にもしが最も減弱している。 性別では L，N及びMの 1 時間值は健康者と同様に女子 が男子より大きいが，24時間值では男子が女子より大き い面積を示す。反応面榬と分散比率をみても Lでは面積

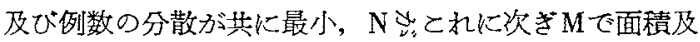
び例数の分散が最も大きい。とれはMに於ては24時間後 KH S Rが異常に增大し, 或は 1 時間後に異常に堌大し て24時間啳には既に減弱する場合が震々認められる結果

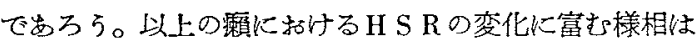
さきに私が瀨患者の毛細管抵抗が甚代易变性でもるとと を報告したととと関連があろう。

议尿器疾患で法大体健康者の反応面積に類似した結果 を得たが，その平均值を比較すると，腎結石 $519.0 \mathrm{~mm}^{2}$ $>$ 腎結核 $290.9 \mathrm{~mm}^{2}>$ 前立腺肥大症 $286.2 \mathrm{~mm}^{2}>$ 睪上体結 核 $177.4 \mathrm{~mm}^{2}>$ 無尿症 $85.8 \mathrm{~mm}^{2}$ の順となる。陰茎癌以よ る悪夜質の 1 例は面積の增大 $\left(1523.0 \mathrm{~mm}^{2}\right)$ にかかから ず全く発赤を表わさず，胃癌の 2 例も面積 $\left(682.5 \mathrm{~mm}^{2}\right.$, $\left.302.4 \mathrm{~mm}^{2}\right)$ に比べて紅さが軽い（一，土），糖尿病では 面積は小さく(平均 $\left.68.8 \mathrm{~mm}^{2}\right)$, 且つ紅さも哥い(十, \pm )。

Freeman 5), Godney ${ }^{8)}$ ，秋谷氏 ${ }^{3)}$ 等によれば，悪性 腫場がHを持つているか否かは未だ明確にされていない し，それ対する特異的なH排制因子る亦不明といら。


制因子との間に平行関係があると述べているから，非特 異的 H-Inhibitor の存在, 悪性腫筸比来する Toxin の 影響す考えられる。しかし癌腫による全体の生活力減退 と基すくさべての反忘力の低下があり，他方組織透過性 の聂進と毛細管のActivity の減费が考えられるから, 陰 茎混の如く，面積が大きいにかかわらず発赤が表明され ぬととも出つてょい。同樣に糖尿病の際のH S R の減弱 は糖質代謝異常に基つくく機能低下と考えれば理解し易

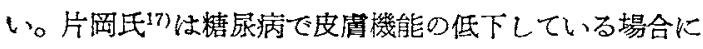
Insulin を注射すると皮南機能が高められると述へてい る。

Mac Clean, Meyer, Dubos, Smyth 等に始る Hyalur onidase 及びその Inhibitor に関する研究は脸下垂体副腎
皮質系機能との関係を解明しょらとしている。例えばA C T H及びCortison がHの作用を著明に抑制するととも

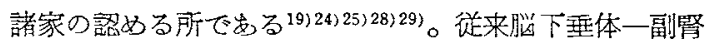
系機能を智い知る方法として Thorn等29) が検討し(A C T H 25mg注射)，その簡便法として Epinephrin一test が提唱されたが，William R. Best ${ }^{32)}$ Schwartz，大森氏 ${ }^{23}$ 等俚本試験が何等悩下垂体一副腎皮質系機能を示すすの でなく、臨彇的価值についても多くの疑義があると反対 し, 平木氏は細䌃内皮系の機能が徤全で岗るととを前提 とすると述へてているしかし A C Eが皮内比ける色素 の㹡散を扣制なるとと年，副婜剔出動物では色素の摭散 が速くしかるAＣEがてれを抑制するととと並んで24， A C T H投与後は血清中の H-Inhibitor が增加するのは 副腎皮質ホルニンにより結合織何等かの変化が起つた ととを示すすのであるとの意見が出る ${ }^{25)}$ 。Tineston et Schumanはかかる抑制効果学䣼素々同時に皮内に湿合注 射した色素の泫散消失時間を測り，Stressによるその数 值の変動により下垂体一副婜皮質系機能を知るうとした この色素消失時間の延長率を示標とする機能検查法は林 氏 ${ }^{11)}$ ，放本・村上・大沢氏等19日大つて行われたが，そ の成績は何れる Adrenalin-stress による Eosinolytic-test と Hyaluronidase-Skin-test の間に密接な関連があるもの の如く，との方法とそ有用な下垂体一副腎譏能を知るも のであると述べている。組織透過性が昂進すればH S R は大となり，色素の消失時閒も短縮する等であるし， Adrenalin-test は必ずしもH S Rを抑制するすのでない 33)方，色素消失時留延展率とH S R は平行関係を保つ ものと思われる。従つて私が今回立場をかえて一定時間 内の拡散面積，即ちH S R と Adrenalin-test との関連を

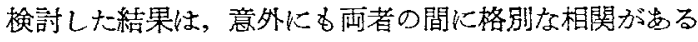
とは考えられない。しかし同一個体について疾患の経過 と共にこの両試験法の成績を追求すると, 或る程度関連 性のある個体も見られているから，早急に結論は下し得 ない。安部・三浦氏等㣙疾病の経過に従つてACTH-test. Adrenalin-test 行つた結果は必ずしもACTH-test が臨 林庭状と平行した結果を示するのでないと述べている。

\section{結語}

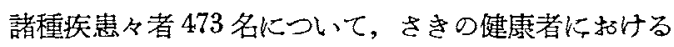
と同一方法によりH S Rを測定した。

1. 皮有疾患々者のH S Rは色素を混した場合の成績 と同しく，㹡散面積から 3 群に分けられる。最高値を示 したすのは皮苚炎, 急性湿疹, 慢性湿疮の增悪期, エy テマトーデス，膿皮症，バザン紅斑，結節性紅斑，紫斑 
病, 天疮瘡及び慢性尌糜侩などの急性出性, フレルギ 一病変が要る $\left(500 \sim 950 \mathrm{~mm}^{2}\right)$ 。中等值を示したすのは

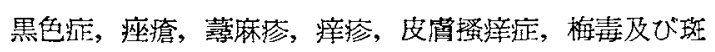
紋制があり $\left(300 \sim 500 \mathrm{~mm}^{2}\right)$, 最低值を示したものに慢

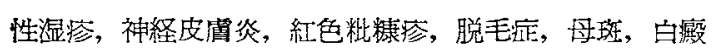

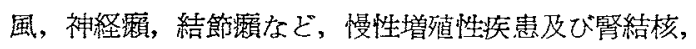
睪上体結核, 前立腺肥大症, 無尿应などが含まれる(300 $\mathrm{mm}^{2}$ 以下)。

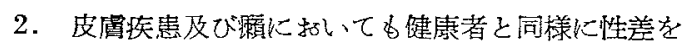
認め，女子子が男子より大きい上らでめる。

3.一般に反応面積が大であれば潮紅も強いか゚，例外 が少数に見られた。

4. 顀ではH S R陰性のものが相当率に見られ(L， $13.3 \%, \mathrm{~N}, 6.1 \%, \mathrm{M}, 21.4 \%$ ) 同様の現象が癌の 3 例火見られた。

5. H S R と好酸球減少率の間には相関性を認めない

6. 皮闻疾患の経過とH S R と好酸球減少率の間比 必ずしも関連性があるとは思われない。

(本論交の要旨は昭和 29 年 11 月第 1 回西部湺学会で発 表した。稿を終るに臨み御愁篤なる御指導と御校閲を睗 わつ大恩師荒川教授並に御援助を賜方つた野島園長に深 甚の謝意を捧げる)

\section{参若文献}

1. 荒川忠良 (1950)：臨皮泌・4 (12)，487 (1952): 皮性誌・62(4)，65 (1955) : 最新医学 10 (5), 45

2. 荒川忠良, 他 (1952) : 最新医学・7 (11), 1205

3. 秋谷七郎 (1952)：スプラーセ女献集 I（持田）

4. 安部・三浦 (1953): 皮之必・15 (5)，29

5. Freeman M.E.: Proc. Soc. Exp. Biol. Med. 70, 524 (1949)

6. 福田 保 (1952): 臨外・7 (13), 743

7. 藤沢勝久 (1953) : 皮性誌 - 63 (8), 495

8. Godney G. : J. B. C. 183, 739 (1950)

9. 後藤 本 (1954): 皮々泌・16 (2), 16

10. Hench: Arch. Inter. Med. 85 (4), 545 (1950)

11. 林, 他 (1952) : 最新医学・7 (10), 1091

12. 井口已広, 他 (1953): 榣皮泌・7 (1)， 24

$$
\text { (1953)：皮紀要・49(4)，218 }
$$

13. 井口曰広 (1956)：レプラ投稿中

14. 出村光一 (1953)：皮性誌・63 (9), 574

15. 北村精一 (1949): 臨床之研究・26 (2), 60

16. 北村, 他 (1953)：日医新・1518
17. 片阍八束 (1953)：臨皮速・7 (12)，738

18. 三上二郎 (1948)：日新医学・35 (12), 512

19. 村上・大沢 (1944)：皮と必・16 (2)，16

20. 三木録三 (1937)：皮性誌・42, 531

21. 野口義国 (1951)：縮合医学·8 (6), (1951): 皮性誌・61 (4)，1291

22. 中村, 他 (1955)：臨皮泌・9 (13)，23

23. 大森精一 (1953): 臨皮必・7 (12), 796

24. Opsahe J. C.: Yale, Biol, Med. 21, 255 (1949)

25. Shuman et al: Proc. Soc. Exp. Biol. Med. 73, 248 (1950)

26. 斎藤豊一 (1951)：泌尿誌・ $42(8), 361$

27. 洗沢喜守堆 (1953)：診断と治療・41 (3), 12

28. 谷奥喜平 (1953)：皮性誌・63 (7)，407

29. Thorn et al: Science. 105, 528 (1947)

T.A.M.A. (日本版) 1 (5)，(1948)

30. 吉田益次郎 (1951) : 最新医学 - 6 (9), 22

31. 吉松孝治 (1952)：皮と泌，13，372

32. William R. Best: J.A.M.A. (日本版) 15 (1), (1953)

33. 武田已広 (1956)：レプラ投稿中。 
Fig. 1. 皮唐疾患々者の H S R

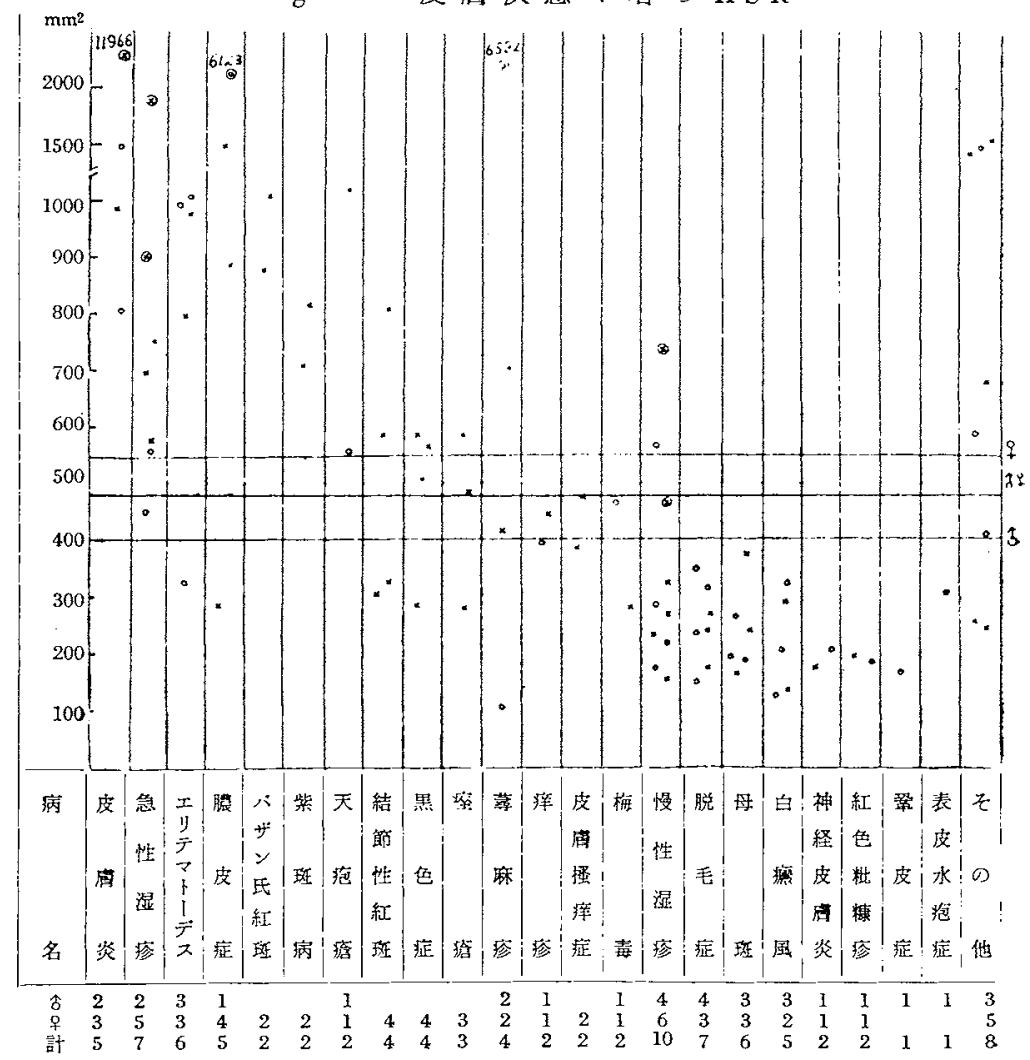

Fig. 2. 攋患者 HSR の分有 (平均)

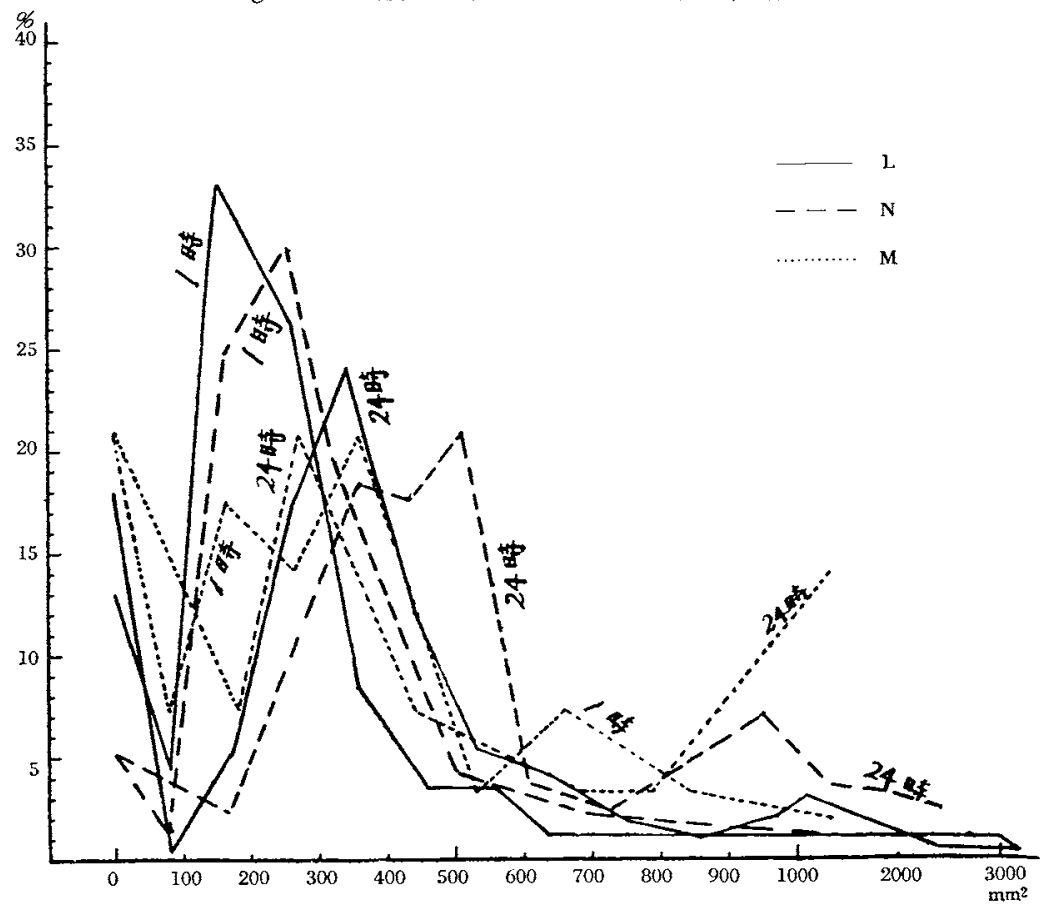


Tab. 1. 皮淍疾患怙上び健康者のH S R 分布

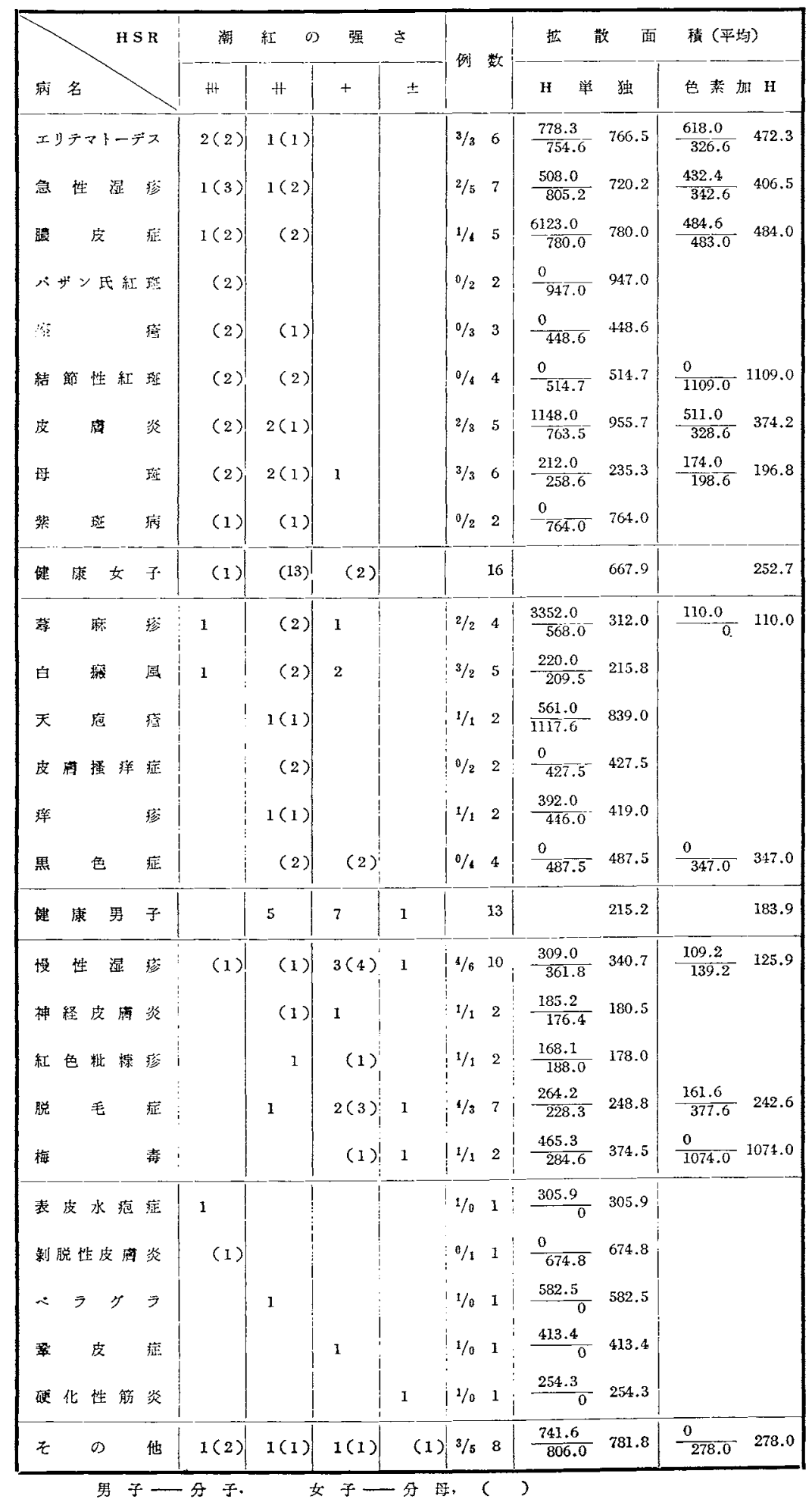


Tab. 2. 瀨患者 $9 \mathrm{H} S \mathrm{R}$ (平均)

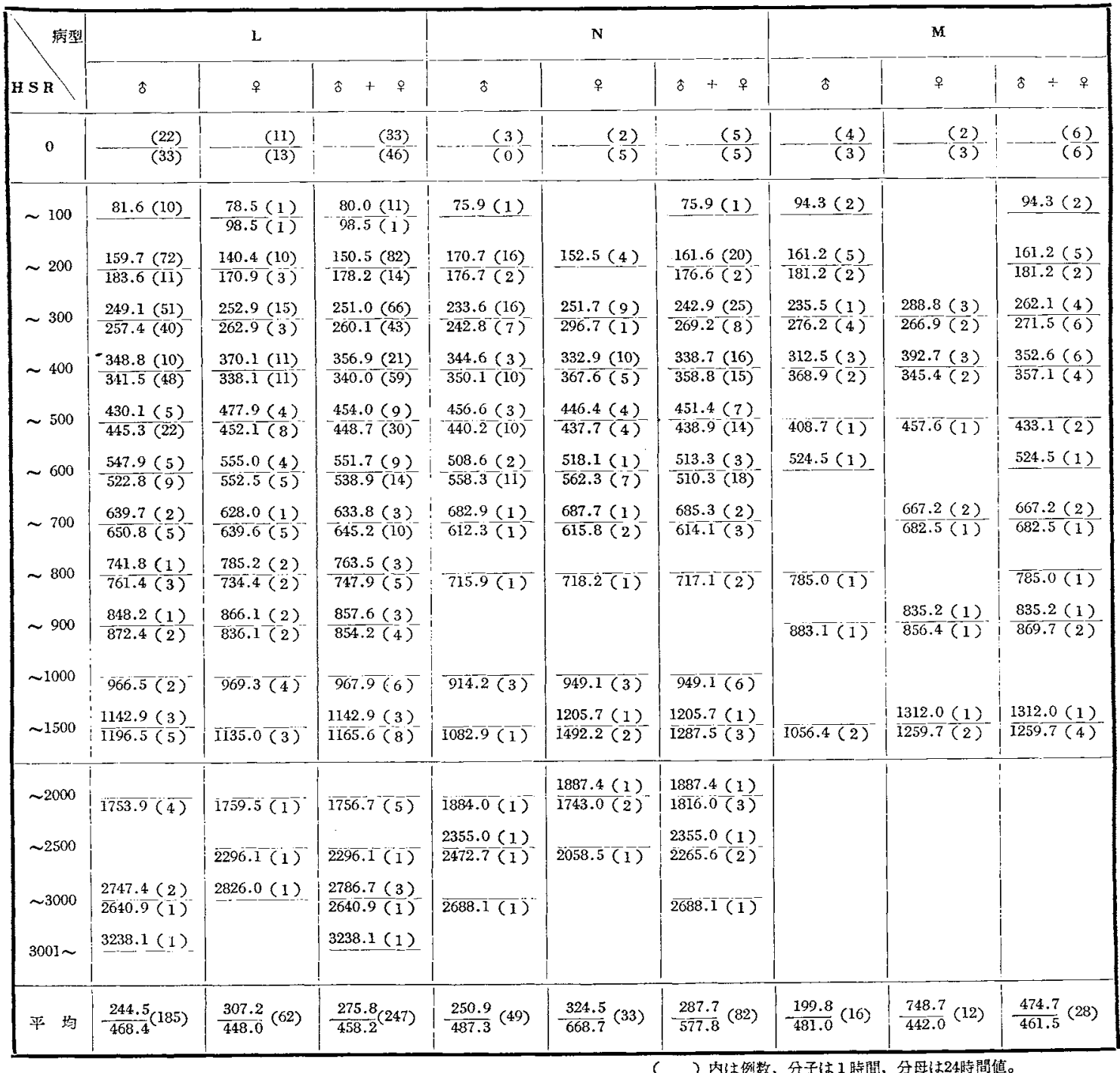


Fig. 3. 议尿器矩患其他に打けるH S R

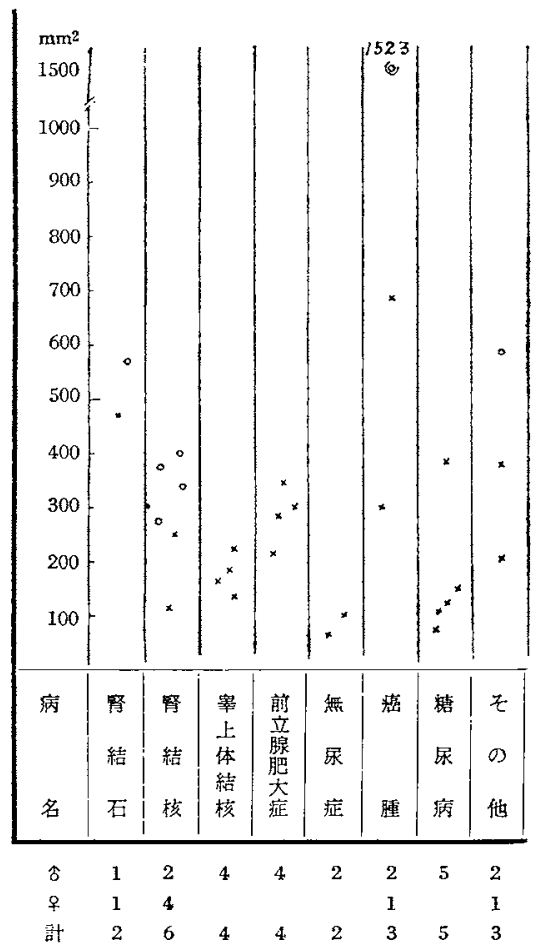

Fig. 4. 好酸球減少率之H S R

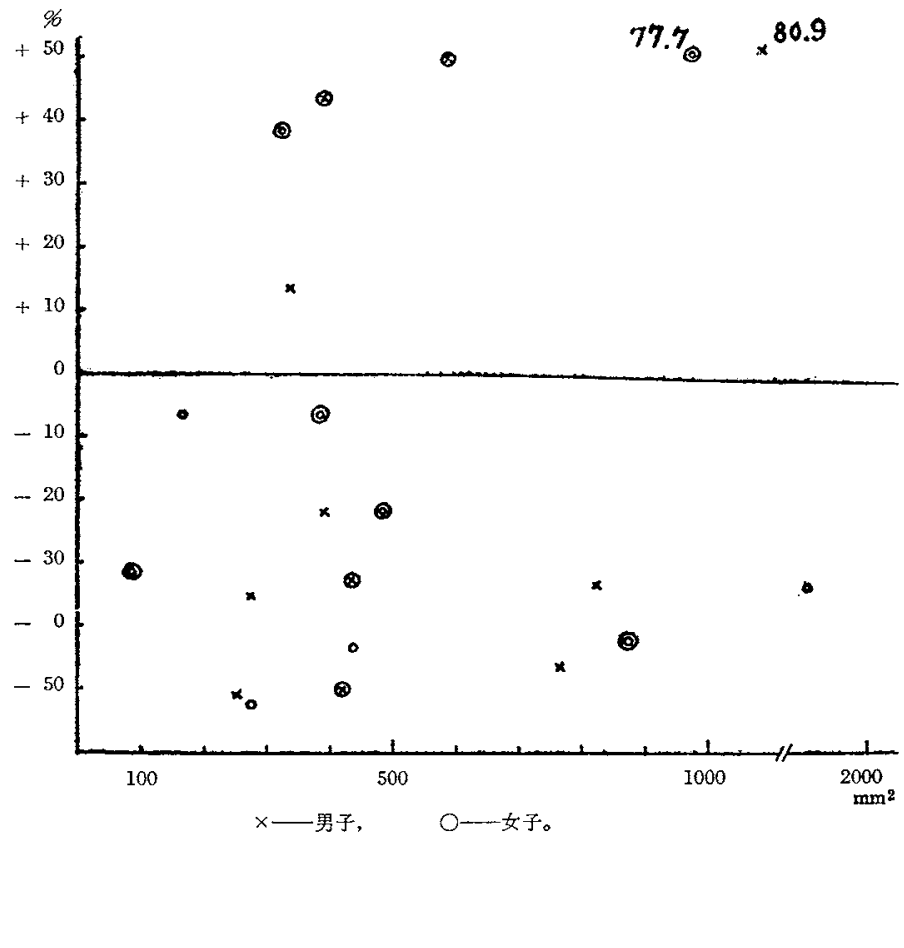

Fig. 5. 疾病経過比打ける反応面積と好酸球減少率の変化

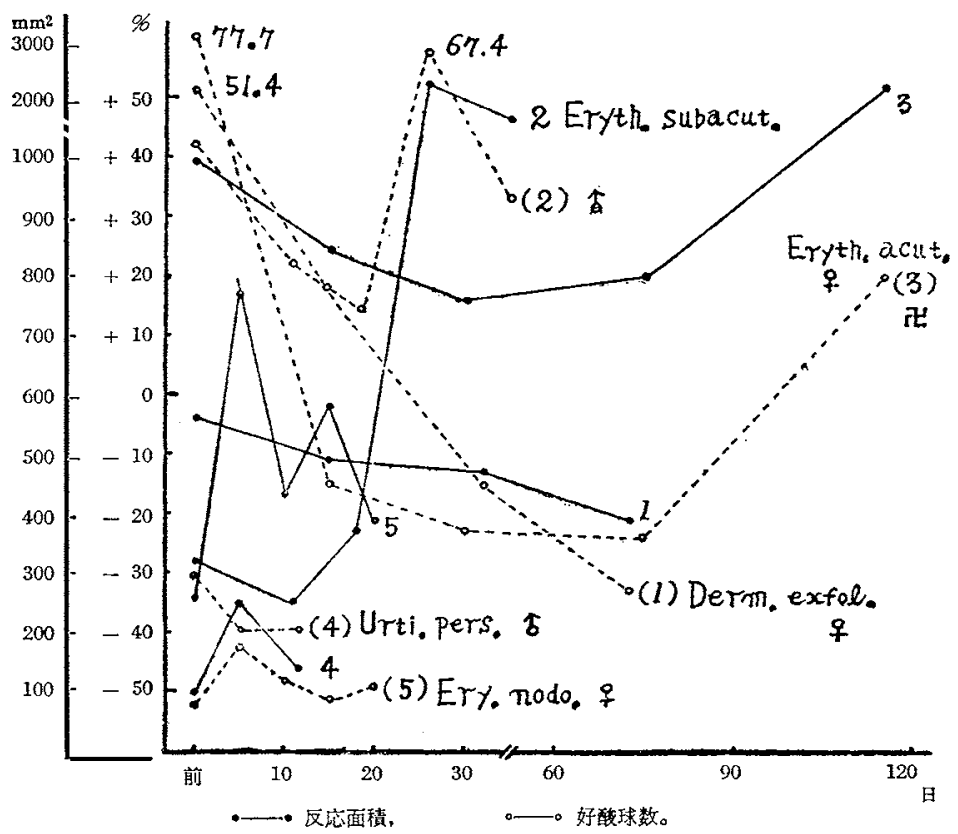

